\title{
DIE VERLEDE AS EERSTE BEHANDELING
}

MARIUS SWART

\section{DIE PASIËNT — 'N MENS MET 'N VERLEDE}

Elke pasiënt het 'n historiese-, sosiale-, kulturele-, skolastiese-, religieuse-, sielkundige- en siekteverlede. Tydens die opleidingsjare ontvang verpleegkundiges dan ook onderrig in, onder andere, Sosiologie en Psigologie - saam met professionele, praktiese afronding.

Selfs onder die verbysterendste omstandighede word 'n pasiënt so ver en so veel as moontlik vóóraf oor sy verlede uitgevra eerdat met enige behandeling begin of terwyl daar met verdere behandeling gevorder word.

Die verlede van 'n pasiënt is daarom die inleidende behandeling wanneer hy aanmeld. Sy eie wording word volledig ontleed geslag, bevolkingsgroep, allergië, littekens, vorige siektes en operasies, beroep, medisynegebruik, tatoeëermerke, aard van beserings vroeër of pas opgedoen en afwykende gesondheidsverskynsels.

Hierdie onderwerping aan en oopvlekking van die verlede van 'n pasiënt is dikwels 'n groter trauma as die werklike siekte of besering wat beleef word. Niks reduseer die mens dan ook sodanig tot gelykvlakkigheid as die enerse hoogte van 'n hospitaalbed nie. Vir 'n tydperk van siekte moet ook 'n leier, 'n bestuurder of 'n gesagdraer van gister hom aan die vrae en ondersoeke van verpleegkundiges onderwerp. Hy word deur vrae ontbloot en deur andere se opdragte en reëlings aan gesag onderwerp - dikwels verpleegkundiges van slegs 18 , 20 jaar oud.

Mense beïnvloed nou maar eenmaal mekaar en verpleegkundiges in die besonder het onder sodanige omstandighede " $n$ uitwerking op die gemoed van pasiënte.

Prof M Swart

Departement Geskiedenis,

Universiteit van Port Elizabeth

\section{SUMMARY}

On admission to hospital a patient is questioned about his past - this thus being introductory treatment.

The author goes on to illustrate that nurses through the ages have used their skills not only to treat patients, but also to alter circumstances to the patients' advantage. The patient brings his personal, cultural and religious past into hospital with him and cognisance must be taken of this if we wish to succeed in our professional task.

\section{Florence Nightingale}

Die verlede rakende die verpleegkunde self toon natuurlik "n interessante geskakeerdheid. Florence Nightingale byvoorbeeld (1820 1910) het nie gepresteer as die dame met die lamp nie; nie in die eerste plek nie. Daardie stories is dikwels 'n mite. Sy het aandag getrek omdat sy, grootliks sonder opleiding, meedoënloos, energiek, eiesinnig en selfs astrant die Britse neëntiende eeuse militêre owerhede se gesondheidsbepalings, of die gebrek daaraan, uitgedaag het. Sy het naamlik leemtes in die tradisionele stelsels raakgesien, dit uitgewys en dit met ander, eie aanbevelings vervang.

Dit geld nog steeds. Verpleegkundiges sal beslis hulle opleiding benut, die verwerfde kennis met gesag en vertroue toepas, maar hulle sal steeds die oé en ore oop hou vir geleenthede om die bestaande te verbeter; nie domweg net te wil verander nie. Dit sal ook makliker kán gebeur indien elke nuwe pasiënt nie bloot as nóg in geval van blindederm, slangbyt, motorongeluk of kanker beskou word nie.

Telkens is 'n nuwe pasiënt die enkeling met 'n eiesoortige agtergrond en verlede. Sodanige iemand reageer op ' $n$ heel persoonlike wyse op haar siektebelewenis. Sy verteenwoordig immers 'n gesin, of 'n beroep en 'n taalgroep, maar sy is in die finale plek, synde mens, die kroon op die skepping - ongeag liggaamlike en geestelike verval of aantasting deur 'n leefwyse of siektetoestand.

Florence Nightingale was wetenskaplik, sy het verpleegkundige kennis uitgeruil, sy was volledig, noukeurig en sy het die teorie met die praktyk gesinkroniseer. Vooroordeel en burokrasie is afgetakel, en onkunde is opgeklaar. Sy het die gemoed van haar pasiënte saam met hulle wonde afgespoel en behandel. Persoonlike agting vir elke enkeling was die wagwoord. Haar belangstelling in die totale mens was opreg. Vir haar hulp aan die Turke tydens die Krimoorlog (1853 - 1856), het sy van die sultan van Turkye dan ook 'n diamant armband ontvang _- want haar eie mense se vyande was waardig genoeg beskou om sinvol behandel te word.

Die hedendaagse verpleegkundige moet soortgelyk die inhoud van haar gesprek met kollegas, geneeshere en amptenare verdiep en verruim. Jonger verpleegkundiges móét in vakjoernale skryf omdat húlle die verlede-instellings op ' $n$ ander manier beleef as wat die gebruike van jare deur senior gesagdraers ondervind word. Dit weer is nodig omdat die heil van pasiënte op die spel is. Reeds Florence Nightingale het vir haar herstellende pasiënte in 1860 se jare leesgeriewe, studiegeleentheid en binnenshuise speletjies bepleit.

\section{MAATSKAPLIKE HELING}

Soortgelyk het Clarissa Harlow Barton (1821 - 1912) as onopgeleide persoon ' $n$ toonaangewende rol in die Amerikaanse verpleegkunde 
gespeel. Sy is tydens die Amerikaanse Burgeroorlog, 1860/65 se jare, die Engel van die Slagveld genoem omdat sy na gewondes se beserings omgesien het, maar ook omdat she made pies and cooked puddings for them.

Vandag sorg dieetkundiges vir gesonde voedsel aan siekes, maar in Clara Barton se tyd het dit om die menslike, die huislike, die persoonlike aandag gegaan. Tans is dit steeds 'n moeilike eis; gewoon omdat te min verpleegkundiges, van wie $60 \%$ getroud is, te veel pasiënte moet versorg. Maar die beginsel van 'n hoë, verantwoordelike, individuele meelewing geld steeds.

Clara Barton het as Amerikaner in 1870 met die Frans-Pruisiese Oorlog die ongevalle help hanteer. Daarna het sy voorraad aan $\mathrm{Ku}$ baanse opstandelinge en aan Amerikaanse onderdane in die Spaans-Amerikaanse Oorlog van 1898 voorsien. Vrou alleen het hierdie eerste voorsitster van die Amerikaanse Rooi Kruis (1882) die owerhede oortuig dat nie net oorlogswonde en normale siektes die aandag van die staat verdien nie, maar ook die slagoffers van hongersnood, rampe, epidemies en ander ellendes.

Derdens was daar Emily Hobhouse (1860 - 1926). Ook hierdie merkwaardige vrou het geen verpleegkundige opleiding gehad nie. Maar as Britse onderdaan was sy beskikbaar vir maatskaplike diens in die VSA, en vir verpleegkundige bystand tydens die Eerste Wêreldoorlog in Europa. Vir Suid-Afrika was sy natuurlik in 1900 se jare die Heldin uit die Vreemde.

Die ellende van die Britse konsentrasiekampe wat vir Afrikaners ingestel is, het haar die Britse militêre en politieke owerhede laat aandurf. Sy het verslag op verslag geskryf, die betrokkenes in die kampe besoek en die eens dapper volk uit hulle verslaenheid opgehef deur hulle te leer spin, vir hulself te sorg, kreatief te skep en om bewustelik "n toekomshoop tegemoet te gaan. Geesteswonde het op 'n bomenslike wyse die aandag ontvang.
Die gevolg was dat jong vroue soos Johanna vn Warmelo by die Irene-kamp naby Pretoria en Nellie Hauptfleisch in die Port Elizabethse konsentrasiekamp vrywillig diens gelewer het om liggaam én gees te herstel en te behou. Lord Kitchener het naamlik 'n beleid van verskroeide aarde teen die Afrikaner gevolg en meer as 26000 vroue en kinders het dan ook landwyd in kampe gesterf. Maar sulke enkele vroue het die praktyk aangedurf en inderdaad 'n keerpunt bewerkstellig.

Daarom begryp 'n mens nie die optrede van hedendaagse goeddoeners nie. Hulle skenk hierdie winter 'n kombers, volgende winter 'n koppie sop en die winter daarop 'n sny brood. Hulle verleng die ellende en lyding van andere pleks dat hulle die oorsake uit die verlede in die hede opruim.

Soortgelyk eindig 'n verpleegkundige se taak nie wanneer 'n mislukte selfmoordgeval van wonde herstel het en die hospitaal verlaat nie. Insgelyks moet die dwelmverslaafde nie bloot gehospitaliseer word ná 'n nag van ontwrigting nie. Sodanige gevalle moet skriftelik en berekend onder die aandag gebring en gehou word, want andersins mors ons mekaar se geld en tyd en lewe. Daar moet tot die diepste wese van die verlede van sodanige pasiënte deurgedring word - deur hulle self te help of om diesulke gevalle aan te meld.

By al hierdie vroue genoem, is die hoë mate van persoonlike optrede, van handeling, opvallend. Deur ingryping in die werklike, maar nie-normale situasie, hersien hulle die omstandighede deur aandag, hervorming, opvolging, aanmelding, herrangskikking - én verkry hulle die medewerking van die betrokkenes.

Daar is geen sprake van afbreek van 'n samelewing in die proses dat aandag geskenk of van die gebaande weë afgewyk word nie. Daar bestaan geen verskuilde selfideale of negatiewe verset nie. Met oortuiging, kennis, organisasie, meelewing en toewyding word die omstandighede tot heil van die betrokkenes verander. Dááruit kan dan heling gebore word.

\section{DIE VERPLEEGKUNDIGE SE INGESTELDHEID}

Vandag se dae is die probleme dikwels dieselfde, maar die omstandighede is anders. Verpleegkundiges is goed opgelei; wetenskaplike strukture bestaan - deur spesiale mense uitgewerk. Die getalle studente en dosente by akademies-tersiêre verpleegkundige opleiding betrokke, neem toe. Veral die nagraadse komponent toon pragtige oplewing. Hierdie is dan ook die mense wat vorentoe dáárdie deurbrake gaan help bewerkstellig waardeur samelewings verder diepgrypend geraak gaan word.

Die omvang van die vereistes tydens opleiding verskaf, neem eweneens toe. Vandaar dat verpleegkundiges al hoe meer in 'n verskeidenheid verwante rigtings des te meer in aanvraag is. Die onderskeiding tussen verpleegkundige, geneesheer en noodhulphelper bly egter ten regte sterk beklemtoon, maar geensins meer die geslág van die verpleegkundige nie.

Die verpleegkundiges is immers beroepslui in eie reg; met 'n eiesoortige taak, eiesoortige opleidingsverlede en 'n eiesoortige inspraak. Hulle is deel van 'n span wat die totale mens as pasiënt versorg. In daardie $\sin$ is alle pasiënte mede-afhanklik van die verpleegkundige.

Die lampie wat aangesteek word en die diensgelofte wat verpleegkundiges aflê, as afspraak met God, is daarom geregverdiglik 'n buitengewone oomblik en waarheid in die lewe van sodanige verpleegkundiges.

In daardie sin moet verpleegkundiges help genees en tegelyk swak gesondheid voorkóm. Voorts, hulle is aityd in die totale samelewing aan diens, want die verpleegkundige moet die misbruik van medisyne betyds uitken. Die hoogs tegniese apparate moet deur hulle laat funksioneer word, want 'n onderbreking of ' $n$ foutiewe aanwending kan iemand sy lewe kos. Voedsel, bloed en medisyne moet met vaardigheid, vertroue en met gesag toegedien word. 
Hieruit spruit weer die beginsel van professionaliteit. Verpleegkundiges is professionele mense, lede van 'n professionele beroep. van 'n professionele vereniging. Hulle is nie lede van "n vakbond of arbeidsorganisasie nie. Hulle is nie opgeleide tegnici nie, al werk hulle met hoogs tegnies-mediese en ander wetenskaplike toerusting. Hulle herstel, na alles, liggame sowel as gemoedere.
Omdat die stand van 'n gemoed gewoonlik vanuit die verlede medebepaal word, leer die verpleegkundiges tussen humanisme en filantropiese verskille deels, en Skriftuurlike en kulturele oortuigings andersins, onderskei. Sou 'n verpleegkundige self minder klem op geloof, gebed, kulturele identiteit en verledevorming plaas, geld dit byna altyd nie vir die pasiënt nie.
Alle pasiënte reageer op, werk saam ten opsigte van, bevraagteken, verwerp, of begryp die behandeling en optrede van verpleegkundiges vanuit die hoogs eiesoortige, emosionele hoek van 'n sisteem van persoonlike kulturele waardes, wat boonop vanuit 'n eie milieu beleef is, en van 'n religieuse bewussyn wat uit die verlede die siekesaal saam binnegebring is.

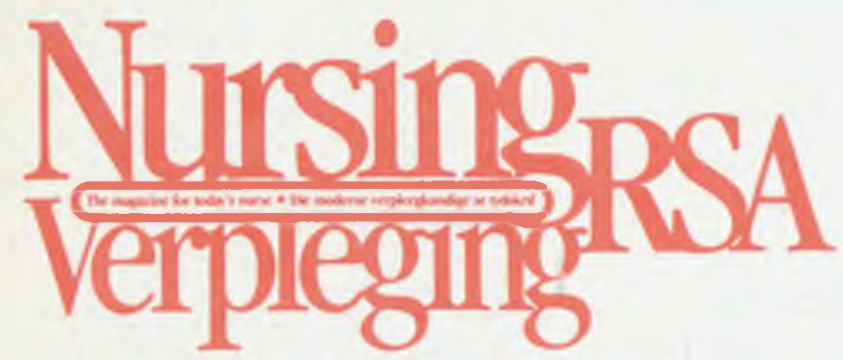

If you're serious about nursing and you thrive on being well-informed. .

\section{SUBSCRIBE NOW}

to Nursing RSA Verpleging - the new bilingual, monthly magazine for today's nurse. Regular readers will enjoy:

- commentaries on important, social, ethical and political issues that confront the profession today.

- Opinions and attitudes of the top working professionals in the field.

- Book reviews.

- Fascinating, personality profiles.

- An in depth RESEARCH SUPPLEMENT.

- 48 pages of glossy, full-colour real-life magazine, of wide general interest, that reflects the nurse of today self confident, modern, assertive.

Written in CLEAR, SIMPLE LANGUAGE, very often about awesome news events at the frontiers of tomorrow's medical research.

\section{'N NUWE MONDSTUK VIR VERPLEGING}

\section{A NEW VOICE FOR NURSING}

Indien u ernstig is oor verpleging en graag goed ingelig wil wees ...

\section{TEKEN NOU IN}

vir Nursing RSA Verpleging - die nuwe tweetalige maandelikse tydskrif vir die hedendaagse verpleegster. Gereelde lesers sal die volgende geniet:

- Kommentaar oor belangrike maatskaplike, etiese en regsvraagstukke wat die beroep vandag in die gesig staar.

- Menings en denkwyses van vooraanstaande werkende beroepslui op dié terrein.

- Boekbesprekings.

- Interessante persoonlikheidsketse.

- 'n Diepgaande NAVORSINGSBYLAE.

- 48 bladsye van 'n aktuele volkleur-glanstydskrif, van wye algemene belang, wat die verpleegster van vandag weerspieël - vol selfvertroue, modern, en wat haarself laat geld.

In DUIDELIKE, EENVOUDIGE TAAL geskryf, baie dikwels oor ontsagwekkende nuusgebeure op die grense van die mediese navorsing van die toekoms.

Yes! I want to be a regular reader of Nursing RSA Verpleging. the bilingual monthly magazine for today's nurse. Please enrol me as a subscriber for one year and post me 12 issues at only R19,25 + R2,31 GST = Total R21,56.

I enclose my payment for R21,56. $\square$ Please charge my credit card.

Type of card Number $\square \square \square \square \square \square \square \square \square \square \square \square$

Signature

PLEASE PRINT AND WHERE POSSIBLE USE YOUR HOME ADDRESS AND NOT YOUR PLACE OF EMPLOYMENT.

NAME SANA Membership No

ADDRESS 


\section{SOCIAL HEALTH}

The youth is continually developing a social role which is satisfying for him and his peers. His gradual withdrawing from his parents and working towards his own adult identity often leaves the young person feeling very vulnerable. This vulnerability leads young people to form groups with a corporate identity which replaces the individual identity which they lack (Mitchell, 1980). Forming groups or gangs often indicates the adolescent's underlying doubt about his ability to cope on his own.

Social health problems in the youth include drug and alcohol abuse. It has been said that abusers and addicts belong to peer groups whose need for expression is not met in any other way. It has also been said that it is not a drug problem as much as a personal problem of the individual who finds either solace, adventure, rebellion, escape or relief in drugs.

Alcohol is the most widely available, best advertised, and cheapest drug of contemporary society (Mitchell, 1980; Clark, 1983). Glue sniffing and inhalant abuse is becoming an increasing problem in the youth (Mitchell, 1980). Drugs most commonly used include heroin, cocaine and morphine derivative drugs. Deliberate overdosage is one of the most frequent causes for admission to hospital in youth (Clark, 1983).

The young person sadly lacks any knowledge of the ill effects of drugs and alcohol. The youth of today must be made aware of these effects and helped to cope with life without these crutches.

\section{NUTRITIONAL HEALTH}

Nutritional health education is very important in the youth, especially for girls but also for boys, who left to their own devices will eat hamburgers and drink coke all day long. During youth girls are preoccupied with appearances and constantly compare their clothes and bodies to that of their peers, probably due to their search for identity and acceptance amongst their peers.

Anorexia nervosa is a problem of girls in their middle adolescent years. These girls are likely to be overweight before commencing their diet. The complications of anorexia nervosa is a phobia of weight gain, secondary amenorrhoea, acute unhappiness and even- tually hypoglycaemic coma and death if not treated.

Obesity is another problem in some young people. Food and eating are used to appease non-nutritional needs and tensions which are erroneously interpreted as desires to eat.

The youth need to be taught nutrition and what comprises a well balanced diet. They also need to be taught how to diet safely and properly.

\section{CONCLUSION}

Constantly responding to variation in experience is what becoming an adult entails. Adolescence is the testing time for the foundations laid in childhood as the inherited personality is shaped and equipped to grow.

It can be seen that the youth is presenting us with the challenge to support them during this transitional stage. It would be tremendous if, in this Year of the Youth. the nurses of South Africa could begin to meet these health educational needs of our youth.

\section{REFERENCES}

Mitchell, R.G. (Ed.) (1980) Child health in the communit London. Churchill Livingstone.

Clark, J.; Henderson, J. (Eds) (1983) Community Healt London. Churchill Livingstone.

Ja! Ek wil 'n gereelde leser van Nursing RSA Verpleging wees, die tweetalige maandelikse tydskrif vir die hedendaagse verpleegster. Skryf my asb. as 'n intekenaar in vir een jaar en stuur my 12 uitgawes vir net R19,25 + $\mathrm{R} 2,31 \mathrm{AVB}=$ Totaal R21,56.

Ek sluit my betaling van R21,56 in. $\square$ Debiteer asb. my kredietkaart.

Tipe kaart ...... Nommer $\square \square|| \perp|\perp||| \square$ Handtekening ......

GEBRUIK DRUKSKRIF EN GEBRUIK ASSEBLIEF WAAR MOONTLIK U HUISADRES EN NIE WERKADRES NIE. 